\title{
Multiple Microvascular Alterations in Pancreatic Islets and Neuroendocrine Tumors of a Men1 Mouse Model
}

\author{
Xia Chu, ${ }^{*}$ Xiang Gao, ${ }^{\dagger}$ Leif Jansson, ${ }^{\dagger}$ My Quach, ${ }^{\dagger}$ Britt Skogseid, ${ }^{*}$ and Andreea Barbu*
}

From the Departments of Medical Sciences* and Cell Biology, ${ }^{\dagger}$ Uppsala University, Uppsala, Sweden

\author{
Accepted for publication \\ February 12, 2013. \\ Address correspondence to \\ Andreea Barbu, Ph.D., Depart- \\ ment of Medical Sciences, \\ Uppsala University, 75185 \\ Uppsala, Sweden. E-mail: \\ andreea.barbu@medsci.uu.se.
}

\begin{abstract}
Vascular therapeutic targeting requires thorough evaluation of the mechanisms activated in the specific context of each particular tumor type. We highlight structural, molecular, and functional microvascular aberrations contributing to development and maintenance of pancreatic neuroendocrine tumors (NETs), with special reference to multiple endocrine neoplasia 1 (MEN1) syndrome, using a Men1 mouse model. Tissue samples were analyzed by immunofluorescence to detect vessel density and pericyte distribution within the endocrine pancreas; expression of angiogenic factors was assessed by immunohistochemistry and quantitative real-time PCR in isolated islets and adenomas cultured under normoxic or hypoxic conditions. The increased vascular density of pancreatic NETs developed in Men1 mice was paralleled by an early and extensive redistribution of pericytes within endocrine tissue. These morphological alterations are supported by, and in some cases preceded by, fine-tuned variations in expression of several angiogenic regulators and are further potentiated by hypoxia. By combining two novel ex vivo and in vivo single-islet and tumor perfusion techniques, we demonstrated that both vascular reactivity and blood perfusion of tumor arterioles are significantly altered in response to glucose and L-nitro-arginine methyl ester. Our findings unravel multiple potential molecular and physiological targets differentially activated in the endocrine pancreas of Men1 mice and highlight the need for in-depth functional studies to fully understand the contribution of each component to development of pancreatic NETs in MEN1 syndrome. (Am J Pathol 2013, 182: 2355-2367; http://dx.doi.org/10.1016/j.ajpath.2013.02.023)
\end{abstract}

Pancreatic neuroendocrine tumors (NETs) are generally welldifferentiated tumors with unique features and high variability in terms of growth pattern and aggressiveness, from nearly benign to highly malignant. In the progression from microscopic lesions to macroscopic tumors, pancreatic NETs become densely packed with cells, outgrowing their vascular supply. This results in a hypoxic environment that restricts further growth, making angiogenesis and vasculogenesis integral parts of tumor progression. ${ }^{1}$ Although targeting the tumor vasculature has become an increasingly attractive approach in the development of new anticancer drugs, such antiangiogenic therapies yield variable results. This is at least partly because each tumor type secretes a distinct panel of angiogenic factors to sustain its own microvascular network. Like normal endocrine tissue, tumors have a dense capillary network. The vascularity is also important in other tumors, including adenocarcinomas of the pancreas, colon, breast, and lung, in which this feature correlates with local invasion, metastasis, and short patient survival. ${ }^{2-5}$ In endocrine pancreatic tumors, however, the relationship between intratumoral microvascular density and tumor prognosis seems to be the opposite of that seen in other types of tumors. ${ }^{6,7}$ This peculiarity was proposed to reflect a unique combination of physiological and adaptive angiogenesis, controlled by distinct, separate regulatory mechanisms. Therapeutic targeting of proangiogenic factors therefore requires a thorough evaluation in the context of pancreatic NET biology.

Multiple endocrine neoplasia 1 (MEN1) syndrome is a genetic disorder with autosomal dominant pattern of inheritance. Both humans and mice with a germline heterozygous loss of function in the MEN1 gene (Men1 in mice), which codes for the protein menin, nearly always develop

\footnotetext{
Supported by the Swedish Cancer Society (110674 to B.S.), the Swedish Research Council (M-521-2011-3668 to B.S.; M-72-109 to L.J.), the Lion's Cancer Research Foundation (B.S.), the Swedish Diabetes Association (L.J.), and the Juvenile Diabetes Research Foundation (L.J.). A.B. was supported by a fellowship from the Swedish Society for Medical Research, The Swedish Society of Medicine, and the Erik, Karin and Gösta Selanders Society.
} 
endocrine tumors. Pancreatic NETs comprise the second most common type of neoplasm in MEN1, after hyperparathyroidism, and their prevalence within MEN1 varies between $30 \%$ and $80 \%$ in different studies. ${ }^{8,9}$ Heterozygous Men1 ${ }^{+/-}$ mice develop pancreatic NETs and other endocrine lesions with a phenotype remarkably similar to that observed in humans with MEN1 syndrome. ${ }^{10}$ Moreover, the age of onset in mice is 9 to 18 months, which is comparable to that in humans, making the $\mathrm{MenI}^{+/-}$mouse a highly informative model, not only for the MEN1 human syndrome but also for the study of specific angiogenic mechanisms activated in slow-growing (months or years) pancreatic NETs. In the present study, we set out to characterize the specific molecular, morphological, and physiological vascular alterations found in the endocrine pancreas and the pancreatic NETs of the Menl mouse model.

\section{Materials and Methods}

\section{Animals}

The Menl mouse model used in the present study is a conventional heterozygous knockout mouse, generated through a Cre-mediated deletion of the second exon of the Menl gene ${ }^{10}$ and was kindly provided by Professor Hayward of the Queensland Institute of Medical Research, Herston, Australia. By 9 months of age, Men1 $1^{+/-}$mice develop pancreatic NETs and, frequently, lesions in the parathyroids, thyroid, adrenal cortex, and pituitary. Most of the pancreatic NETs that develop in these mice express predominantly insulin, and only a limited number produce predominantly glucagon. In the present study, we were not selecting tumors depending on their secretion pattern, and therefore all groups referred to as pancreatic NET include primarily lesions expressing insulin but do not exclude the rare presence of lesions producing other hormones. Homozygous $\mathrm{Men} 1^{+/+}$ mice were used as controls. All animals were housed in microisolator cages on a 12-hour dark/light cycle and were fed a standard diet ad libitum. Maintenance of the animals and all experiments were approved by and performed according to the guidelines and regulations of the local committees for animal care at Uppsala University.

Two age groups were studied: mice 4 to 6 months old, hereafter referred to as young, and mice $>12$ months old, referred to as older.

\section{Islet and Tumor Isolation and Culture}

Pancreatic islets from young $\mathrm{MenI} \mathrm{I}^{+/+}$and $\mathrm{MenI}^{+/-}$mice $(n=6$ per genotype) and tumors and pancreatic islets with macroscopically normal features and normal sizes from the older MenI ${ }^{+/+}$and Men $1^{+/-}$mice $(n=4$ per genotype $)$ were prepared by collagenase digestion as described previously. ${ }^{11}$ This procedure does not eliminate the possibility that the pool of $M e n I^{+/-}$islets from individual animals in the older group might include single hyperplastic islets and/or microtumors of normal islet size. The islets and tumors were subsequently handpicked with braking pipettes under a stereomicroscope (Leica M50; Leica Microsystems, Wetzlar, Germany) and were maintained free-floating in groups of 150 islets at $37^{\circ} \mathrm{C}$ in a $5 \% \mathrm{CO}_{2}$-enriched atmosphere in $5 \mathrm{~mL}$ of RPMI 1640 culture medium (Sigma-Aldrich, Munich, Germany; St. Louis, MO) supplemented with $2 \mathrm{mmol} / \mathrm{L}$ L-glutamine, $11 \mathrm{mmol} / \mathrm{L}$ glucose, $10 \%$ (v/v) fetal calf serum, and $0.1 \mathrm{mg} / \mathrm{mL}$ streptomycin. For hypoxia studies, islets and tumors were incubated under the same conditions except in a hypoxic chamber at $1 \% \mathrm{O}_{2}, 5 \% \mathrm{CO}_{2}$, and $94 \% \mathrm{~N}_{2}$.

\section{Fluorescent Staining of Pancreas Sections}

The following antibodies and dilutions were used: insulin primary antibody (1:200; catalog no. 20-IP30; Fitzgerald Industries International, Acton, MA), secondary antibody fluorescein isothiocyanate-conjugated donkey anti-guinea pig $\operatorname{IgG}(\mathrm{H}+\mathrm{L})$ (1:500; catalog no. 706-096-148; Jackson ImmunoResearch Laboratories, West Grove, PA), antimouse CD31 (1:100; catalog no. 553370; BD Bioscience, San Diego, CA) and secondary antibody Alexa Fluor 594 donkey anti-rat IgG (1:500; catalog no. 21209) (Life Technologies-Invitrogen, Carlsbad, CA), anti-NG2 chondroitin sulfate proteoglycan primary antibody (1:200; catalog no. AB5320; EMD Millipore, Billerica, MA), and secondary antibody fluorescein isothiocyanate-conjugated donkey antirabbit IgG $(\mathrm{H}+\mathrm{L})$ (1:500; catalog no. 711-095-152; Jackson ImmunoResearch Laboratories).

Pancreata from young and older MenI ${ }^{+/-}$mice $(n=4$ per age group) carrying pancreatic NETs were snap-frozen in liquid nitrogen. Cryosections of tissues were fixed for 5 minutes in ice-cold acetone, washed with PBS, blocked in serum-free protein block (Dako, Glostrup, Denmark; Carpinteria, CA) for 10 minutes at room temperature, and then incubated with primary antibodies in PBS supplemented with $2 \%$ bovine serum albumin for 1 hour at room temperature. The slides were then washed in PBS-Tween 20 and incubated with secondary antibody in PBS for 1 hour at room temperature. Sections were mounted with coverslips using Vectashield mounting medium with or without DAPI (Vector Laboratories, Burlingame, CA).

Morphological Evaluation of Blood Vessel Density and Endothelial Cell/Pericyte Proportion

Stained sections were examined under an Axioplan 2 fluorescence microscope at $\times 20$ or $\times 60$ magnification and were analyzed using AxioVision software version 4.8.1 (Carl Zeiss Microscopy, Jena, Germany). Area density of CD31 (for endothelial cells), NG2 (for pericytes), and insulin (for pancreatic endocrine tissue) immunoreactivities was determined with ImageJ software version 1.38 (NIH, Bethesda, MD) on digital fluorescence microscopic images using empirically determined threshold values. Area density was calculated as the proportion of pixels having a fluorescence intensity value equal to or greater than the corresponding threshold. 
Total endothelial cell area and NG2-positive area within the pancreatic endocrine tissue was determined in five sections per mouse, $30 \mu \mathrm{m}$ apart, from four mice per group, except that for NG2 staining for pancreatic NETs two mice were evaluated. These determinations were expressed as mean value per animal or tumor and the endothelial cell/pericyte ratio was considered a single observation.

\section{Perfusion of Single Islets and Pancreatic NETs}

To study islet and pancreatic NET vascular regulation without confounding effects of the exocrine blood vessels, we used an ex vivo single-islet and tumor arteriole perfusion technique. ${ }^{12}$ Briefly, pancreatic NETs isolated from the older Men $1^{+/-}$ mice $(n=7)$ and islets isolated from young $M e n 1^{+/-}$mice $(n$ =6) and $\mathrm{MenI}^{+/+}$mice $(n=7)$ were dissected with their arterioles intact under a stereomicroscope and then transferred onto the stage of an inverted microscope. A holding pipette was used to keep the islet or tumor in place; another pipette, into which the ends of the arterioles were aspired, was used for perfusion. The perfusion pipette was connected to a manometer to adjust the flow to $80 \mathrm{mmHg}$ (approximately $10.64 \mathrm{kPa}$ ) throughout the protocol, and a reservoir containing a perfusion solution [Krebs-Ringer bicarbonate buffer with $10 \%$ HEPES and $1 \%$ bovine serum albumin (KRBH)] supplemented with $5.5 \mathrm{mmol} / \mathrm{L}$ D-glucose. Criteria for using an islet arteriole were maintained basal tone, no pronounced vasodilation, and a rapid and complete constriction in response to administration of $100 \mathrm{mmol} / \mathrm{L} \mathrm{KCl}$ solution. Arterioles were allowed to recover for 10 minutes after the test. Each experiment began with a 15-minute equilibrium period with buffer containing $5.5 \mathrm{mmol} / \mathrm{L}$ glucose in both the bath and perfusion solution. Thereafter, the islets/tumors were subjected to a 15-minute perfusion period with KRBH solution supplemented with $17 \mathrm{mmol} / \mathrm{L}$ D-glucose, followed by another 15-minute perfusion period with KRBH supplemented with $0.1 \mathrm{mmol} / \mathrm{L}$ L-nitro-arginine methyl ester (L-NAME; SigmaAldrich). The experiment was then terminated by administration of $100 \mathrm{mmol} / \mathrm{L} \mathrm{KCl}$, to ascertain that the arterioles were still able to contract.

Images were acquired using a 0.3 -inch chip digital camera (CB-3803S; GKB, Taichung, Taiwan) with a Nikon X60/1.2 water immersion objective (Nikon, Tokyo, Japan), yielding a final magnification of $\times 300$. Data were stored on Super Video (SVR) home-systems videotapes on a video recorder (Panasonic NV-HS830; Matsushita Audio Video, Lüneburg, Germany). These video sequences were digitalized using a frame-grabber card (pciGrabber-4plus; Phytec Technologie Holding, Mainz, Germany), and blood vessel diameters were later analyzed using customized software. This experimental set-up allowed us to continuously measure the diameter of the blood vessels and to record changes at a resolution of $<0.2$ $\mu \mathrm{m}$. In all series of experiments, the average of five images acquired at 1-second intervals was used in the statistical analysis for each time point of the control or treatment periods.

\section{Hydrogen Gas Clearance}

The hydrogen gas clearance technique, which has been extensively evaluated for organ blood flow measurements, ${ }^{13,14}$ was recently adapted for single-islet determinations in mice and rats. Briefly, mice were anesthetized intraperitoneally with $60 \mu \mathrm{g} / \mathrm{g}$ body weight pentobarbital (Apoteksbolaget, Umeå, Sweden) and placed on a heated operating table. A tube was placed in the trachea, and catheters were inserted into the carotid artery, to monitor mean arterial blood pressure using a Druck PDCR 75/1 pressure transducer (GE Measurement and Control, Leicester, UK), and into the left femoral vein to infuse saline, $2 \mathrm{mg} / \mathrm{g}$ body weight D-glucose and $25 \mu \mathrm{g} / \mathrm{g}$ body weight L-NAME.

$\mathrm{H}_{2}$ microelectrodes were polarized with respect to a reference electrode, which was placed in the abdominal muscle. The electrical current obtained is proportional to the hydrogen gas concentration. ${ }^{13,14}$ The microelectrode was inserted under visual control into the islet or pancreatic tumor. A flow of $\mathrm{H}_{2}$ was allowed to pass over the trachea, and the tissue $\mathrm{H}_{2}$ clearance curve was recorded and monitored until it returned to the control levels, before gas loading. This procedure was repeated for the same islet or tumor at 10 minutes after glucose infusion and at 3 minutes after L-NAME infusion. For the present study, we used young $\mathrm{MenI}^{+/+}$and $\mathrm{MenI^{+/- }}$ mice for measuring islet blood perfusion ( $n=6$ and $n=4$, respectively) and the older $\mathrm{Men} \mathrm{I}^{+/-}$mice for measuring pancreatic NET blood perfusion $(n=6)$.

The individual blood flow values were calculated from the slope of the washout curves as described previously, ${ }^{13,14}$ according to the formula $\mathrm{BF}=\ln (2) / \mathrm{TC}$, where $\mathrm{BF}$ is blood flow, $\ln (2)$ is the natural logarithm of $2(0.693)$, and TC is the time for the $\mathrm{H}_{2}$ current to decrease to $50 \%$. The vascular conductance, $C$, of the islets or tumors was further calculated as $C=\mathrm{BF} / \mathrm{BP}$, where $\mathrm{BP}$ is the mean arterial blood pressure.

\section{RNA Isolation and $\mathrm{qPCR}$}

RNA isolation was performed with islets isolated from young $\mathrm{MenI}^{+/-}$and $\mathrm{Men1^{+/+ }}$ mice ( $n=6$ per genotype) and in islets and tumors isolated from the older MenI ${ }^{+/-}$ and $M e n 1^{+/+}$mice ( $n=4$ per genotype). Briefly, RNA was isolated using an RNeasy Plus micro kit (Qiagen, Hilden, Germany; Valencia, CA) according to the manufacturer's instructions. The RNA was eluted with RNase-free water and was stored at $-70^{\circ} \mathrm{C}$. The purity and concentration of the samples were determined by spectrophotometry.

cDNA was synthesized using SuperScript III Reverse Transcriptase (Life Technologies-Invitrogen). Quantitative real-time PCR (qPCR) was then performed using a LightCycler instrument (Roche, Basel, Switzerland) and SYBR Green JumpStart Taq ReadyMix (Sigma-Aldrich). Specific primers for the target genes were purchased from Eurofins MWG Operon (Ebersberg, Germany; Huntsville, AL) and were designed to span exon to exon, to avoid amplification of genomic DNA. The primer sequences are presented in 
Table 1 Primer Sequences Used in the qPCR Studies

\begin{tabular}{|c|c|c|}
\hline $\begin{array}{l}\text { Target } \\
\text { genes }\end{array}$ & Direction & Sequence \\
\hline \multirow[t]{2}{*}{ VEGF-A } & Forward & $5^{\prime}$-ACTTGCAGATGTGACAAGCC-3' \\
\hline & Reverse & 5'-GTGGTGACATGGTTAATCGG-3' \\
\hline \multirow[t]{2}{*}{ VEGFR2 } & Forward & $5^{\prime}-\mathrm{ACA} A \mathrm{ACCCGGCCAAACAA-3^{ \prime }}$ \\
\hline & Reverse & $5^{\prime}-\mathrm{TTCCCCCCTGGAAATCCTC-3^{ \prime }}$ \\
\hline \multirow[t]{2}{*}{ PIGF } & Forward & 5'-CACTCTGCCTGTGTTCCAGA-3' \\
\hline & Reverse & $5^{\prime}$-CTGGAGATGGGACAGGACAT- $3^{\prime}$ \\
\hline \multirow[t]{2}{*}{ FGF2 } & Forward & 5'-CCCGTTTTGGATCCGAGTTT-3' \\
\hline & Reverse & $5^{\prime}$-GTCACGGAAATACTCCAGTTGGT-3' \\
\hline \multirow[t]{2}{*}{ FGFR1 } & Forward & $5^{\prime}$-АACTTCACCGTCTTGGCAGC- $3^{\prime}$ \\
\hline & Reverse & $5^{\prime}$-СTCCCTACTGGACATCCCCA-3' \\
\hline \multirow[t]{2}{*}{ PDGF-BB } & Forward & $5^{\prime}-$ GCAGCCACACCAGGAAG- $3^{\prime}$ \\
\hline & Reverse & $5^{\prime}$-TGTTCCAGATCTCGCGGAAG- $3^{\prime}$ \\
\hline \multirow[t]{2}{*}{ PDGFR- $\beta$} & Forward & 5'-GTCTGTCACTGGCCTCCACCAG-3' \\
\hline & Reverse & 5'-GTGGTGAACTTCCAATGGACG-3' \\
\hline \multirow[t]{2}{*}{ Ang-1 } & Forward & 5'-AGGCTTGGTTTCTCGTCAGA-3' \\
\hline & Reverse & 5'-TCTGCACAGTCTCGAAATGG-3' \\
\hline \multirow[t]{2}{*}{ Ang-2 } & Forward & $5^{\prime}$-CAGCGAATGCGCCTCGTTGC-3' \\
\hline & Reverse & 5'-GCTTCGGGAGCCCTCTGGGA-3' \\
\hline \multirow[t]{2}{*}{ Tie2 } & Forward & $5^{\prime}$-AGACAGTGCTGGAGGGAGAA- $3^{\prime}$ \\
\hline & Reverse & 5'-GAGGAGAAATGGCCGTTGTA-3' \\
\hline \multirow[t]{2}{*}{ HPRT } & Forward & 5'-CGTCGTGATTAGCGATAGTG-3' \\
\hline & Reverse & $5^{\prime}$-ACAGAGGGCCACAATGTGAT-3' \\
\hline \multirow[t]{2}{*}{ TBP } & Forward & $5^{\prime}$-АСССТTCAССАATGACTCСТATG-3' \\
\hline & Reverse & $5^{\prime}$-ATGATGACTGCAGCAAATCGC-3' \\
\hline
\end{tabular}

Table 1. Primers for hypoxanthine-guanine phosphoribosyltransferase (HPRT) and for TATA binding protein (TBP) were used as internal standards. Products were analyzed using melting-curve analysis and gel separation.

\section{Immunohistochemistry}

The following antibodies and dilutions were used: menin (1:400; polyclonal; catalog no. 572; Bethyl Laboratories, Montgomery, TX), insulin (1:200; polyclonal; catalog no. 20-IP30; Fitzgerald Industries International), glucagon (1:1000; polyclonal; catalog no. A0565; Dako), HIF-1 $\alpha$ (1:200; polyclonal; catalog no. NB100-134; Novus Biologicals, Littleton, CO), VEGF (1:100; polyclonal; catalog no. ab46154; Abcam, Cambridge, UK), FGFR1 (1:400; polyclonal; catalog no. ab10646; Abcam), FGF2 (1:100; polyclonal; catalog no. ab106245; Abcam), PDGF-B (1:200; polyclonal; catalog no. sc127; Santa Cruz Biotechnology, Santa Cruz, CA), angiopoietin-1 (1:200; polyclonal; catalog no. ab8451; Abcam), angiopoietin-2 (1:400; catalog no. ab8452, polyclonal, Abcam). All antibodies were diluted in antibody diluent (Dako).

Consecutive pancreatic sections from young $\mathrm{MenI}^{+/+}$and $M e n 1^{+/-}$mice ( $n=3$ per genotype) and from the older Men $1^{+/-}$mice $(n=3)$ were mounted on glass slides, deparaffinized, rehydrated, and epitope heat-retrieved in citrate buffer (pH 6.0) (Dako). Sections were stained with primary antibodies for 1 hour at room temperature, washed, and incubated with specific secondary antibodies for 45 minutes at room temperature. Sections were then developed with an EnVision kit (Dako), to visualize the targeted proteins. All tissues were counterstained with Mayer's hematoxylin, mounted, and evaluated under an Axioplan 2 light microscope, using an AxioCam HRm camera and AxioVision imaging software version 4.8.1 (Carl Zeiss).

\section{Statistical Analysis}

Data are expressed as means \pm SEM. Probabilities $(P)$ of chance differences between the groups were calculated with analysis of variance for normally distributed values and $U$-test for nonparametric values. All calculations were made using SigmaStat software version 11.0 (SSSP; Systat Software, San Jose, CA).

\section{Results}

Menin was ubiquitously expressed in the pancreatic islets of young $\mathrm{Men1^{+/ }}$ mice ( $n=3$ mice, $n=100$ islets), indicating the presence of a fully functional Menl wild-type allele in all pancreatic endocrine cells at this age. In the older Men $1^{+/-}$ mice ( $n=3$ mice, $n=133$ islets), immunohistochemical analysis demonstrated that, in $6.8 \%$ of all islets with macroscopically normal features and normal sizes, nuclear menin expression was lost in all or at least some of the endocrine cells.

\section{Vascular Remodeling in Islets and Pancreatic NETs} from Men1 ${ }^{+/-}$Mice

Despite the increased microvascular density, the structure of the vasculature in $\mathrm{Men1^{+/ }}$ islets was similar to that of the control MenI ${ }^{+/+}$islets (Figure 1A). Endothelial cell counts were significantly increased in $\mathrm{Men1^{+/ }}$ pancreatic NETs, compared with $\mathrm{MenI}^{+/+}$islets $(11.64 \pm 1.73 \%$ versus $3.26 \pm$ $0.42 \%$ ), as visualized by staining with CD31. Even the fractional vascular area of normal-sized islets in $\mathrm{MenI}^{+/-}$mice was significantly increased, relative to age-matched control Menl $^{+/+}$islets $(6.08 \pm 0.68 \%$ versus $3.26 \pm 0.42 \%)$ (Figure 1B), although this difference was observed only in the older mice. As already noted, for these older mice we cannot exclude the possibility that approximately $7 \%$ of the islets might be microadenomas.

Blood vessels of the pancreatic NETs had multiple abnormalities that have been described previously in other tumors, ${ }^{15}$ including variability in size, thickness and tortuosity, as well as vascular mimicry, glomeruloid vascular proliferations, and arteriovenogenesis (Figure 1A).

\section{Differential Angiogenic Gene Expression in Islets and Pancreatic NETs Isolated from Men1 ${ }^{+/-}$Mice}

The expression of VEGF-A was increased after hypoxic challenge both in islets isolated from young mice, as well as in islets and tumors isolated from the older mice. During normoxia, however, VEGF-A mRNA levels were not significantly different in the endocrine tissues isolated from young $\mathrm{MenI}^{+/-}$mice, compared with age-matched $\mathrm{MenI}^{+/+}$mice 


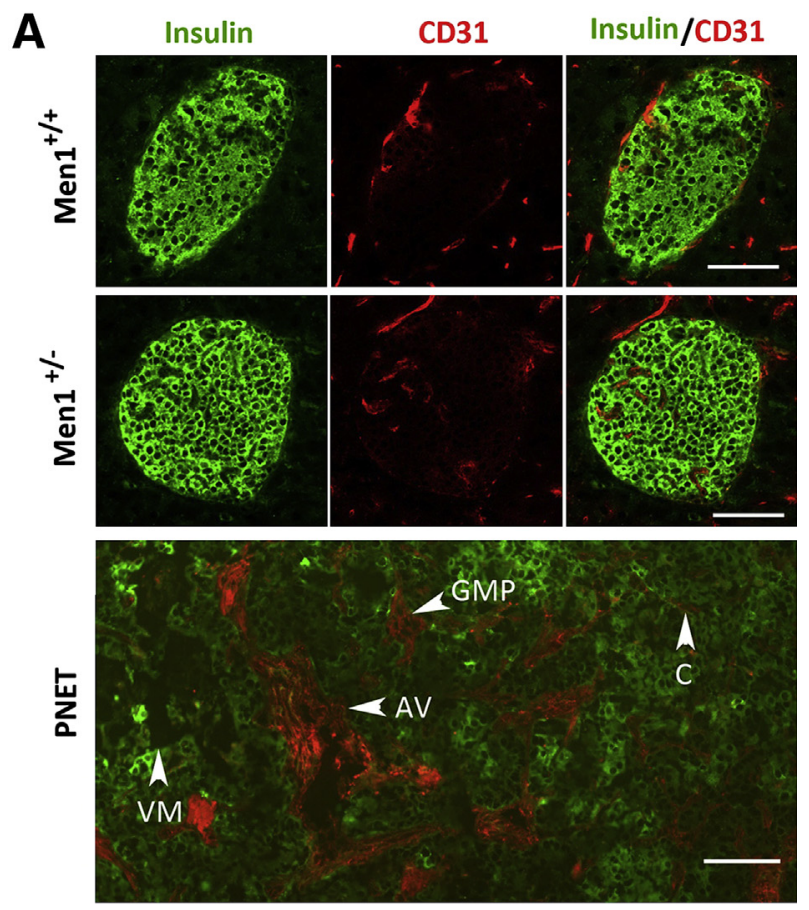

B

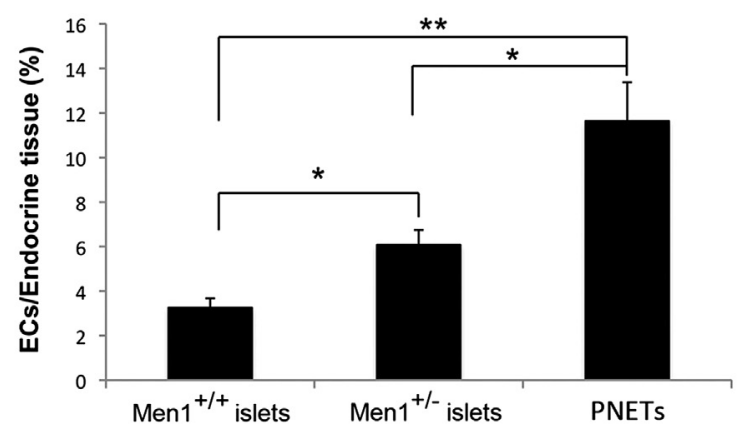

Figure 1 Altered vascular morphology in the endocrine pancreas of Men1 ${ }^{+/-}$mice. A: Representative micrographs show endothelial distribution (red staining for CD31-positive endothelial cells) within the endocrine pancreas (insulin-positive endocrine cells stain green) in $M e n 1^{+/+}$mice, normal endocrine tissue from Men1 $1^{+/-}$mice, and pancreatic NETs from $M e n 1^{+/-}$mice. B: Endothelial cells and endocrine tissue quantification in $M e n 1^{+/+}$endocrine pancreas, Men1 $1^{+/-}$normal endocrine pancreas, and Men1 ${ }^{+/-}$pancreatic NETs. Data are expressed as means \pm SEM. ${ }^{*} P<0.05$, $* * P<0.01$ one-way analysis of variance and Bonferroni's post hoc test. Scale bar $=100 \mu \mathrm{m}$. AV, arteriovenogenesis; C, capillaries; EC, endothelial cell; GMP, glomeruloid vascular proliferations; PNET, pancreatic neuroendocrine tumor; VM, vascular mimicry.

(Figure 2, A and B), and neither was the twofold increase $(P=0.086)$ in VEGFR2 mRNA levels in $M e n 1^{+/-}$islets, compared with $\mathrm{Menl^{+/+ }}$ islets under normoxic conditions (Figure 2C). In tumors, VEGFR2 mRNA expression was up-regulated, reaching a 3.5-fold increase in normoxia and a 7.8-fold increase in hypoxia (Figure 2D). mRNA expression of placenta growth factor (PlGF) was up-regulated in islets isolated from young animals cultured under hypoxic conditions (1.9-fold increase in $\mathrm{MenI}^{+/-}$versus $\mathrm{MenI}^{+/+}$islets) (Figure 2E). We also observed a dramatic induction of PIGF expression in tumors, further potentiated by hypoxia (Figure 2F).
FGF2 and FGFR1 mRNA expression was significantly increased in isolated pancreatic NETs when challenged with hypoxia for 6 hours, compared with age-matched MenI ${ }^{+/+}$ and $\mathrm{MenI}^{+/-}$islets: a 12.7-fold increase for FGFR1 and a 4.2-fold increase for FGF2 expression (Figure 3, B and D). Under normoxic conditions, however, these differences did not reach significance: a twofold increase in pancreatic NETs versus $M e n 1^{+/-}$islets for FGFR1 $(P=0.256)$ and a 1.5 -fold increase in pancreatic NETs versus $\mathrm{MenI}^{+/-}$islets for FGF2 $(P=0.178)$ (Figure 3). Moreover, FGFR1 islet expression was already up-regulated in young $\mathrm{Men1^{+/- }}$ mice (1.8-fold increase in $\mathrm{Menl}^{+/-}$versus $\mathrm{Menl} \mathrm{I}^{+/+}$islets; $\left.P=0.065\right)$, before formation of endocrine lesions, and this difference was further potentiated by hypoxic conditions (Figure 3C).

\section{Altered Vascular Reactivity in Islet and Tumor Arterioles Isolated from Men1 ${ }^{+/-}$Mice}

Administration of $17 \mathrm{mmol} / \mathrm{L}$ D-glucose in the perfusion medium caused an $8 \%$ vasodilation of the arterioles in $\mathrm{MenI}^{+/+}$islets and a $4.5 \%$ vasodilation of the arterioles in $\mathrm{MenI}^{+/-}$islets, but only a $2 \%$ vasodilation of the arterioles supplying the NETs isolated from $M e n 1^{+/-}$mice (Figure 4). L-NAME caused a pronounced constriction of the islet arterioles isolated from both $\mathrm{MenI}^{+/+}$and $\mathrm{MenI} \mathrm{I}^{+/-}$mice, with a maximum constriction of $9 \%$ and $10 \%$, respectively, after 15 minutes of perfusion. Notably, arterioles of Men $1^{+\prime-}$ pancreatic NETs also exhibited constriction in response to L-NAME administration, and the maximal vasoconstriction attained was significantly increased, to $17 \%$ (Figure 4).

\section{Altered Blood Perfusion in Men1 ${ }^{+/-}$Islets and Pancreatic NETs}

Administration of $\mathrm{H}_{2}$ led to a decrease (usually by $10 \%$ to $25 \%$ ) in mean arterial blood pressure. To correct for this, we express these data as vascular conductance (as defined under Materials and Methods). Men1 $1^{+-}$islets and pancreatic NETs showed a tendency toward an increased basal vascular conductance, compared with $\mathrm{Menl}^{+/+}$islets $\left(\mathrm{MenI}^{+/-}\right.$islets, $0.007 \pm 0.003$ minute $^{-1}$; pancreatic NETs, $0.011 \pm 0.002$ minute $^{-1}$; MenI ${ }^{+/+}$islets, $0.004 \pm 0.002$ minute $\left.^{-1}\right)$, but the difference did not reach statistical significance $\left(P=0.077\right.$, pancreatic NETs versus Men $1^{+/+}$ islets) (Figure 5A). Glucose administration induced an increased blood flow in $\mathrm{Men1^{+/+ }}$ islets, which was significantly attenuated in $M e n 1^{+/-}$islets and pancreatic NETs. Blood perfusion was significantly decreased by nitric oxide (NO) inhibition in all groups (Figure 5B).

\section{Pericyte Redistribution in Men1 ${ }^{+/-}$Islets and Pancreatic NETs}

Pericytes, identified by NG2 immunoreactivity, were more abundant in normal-sized $\mathrm{Menl}^{+/-}$islets isolated from young mice, compared with age-matched $M e n 1^{+/+}$islets 

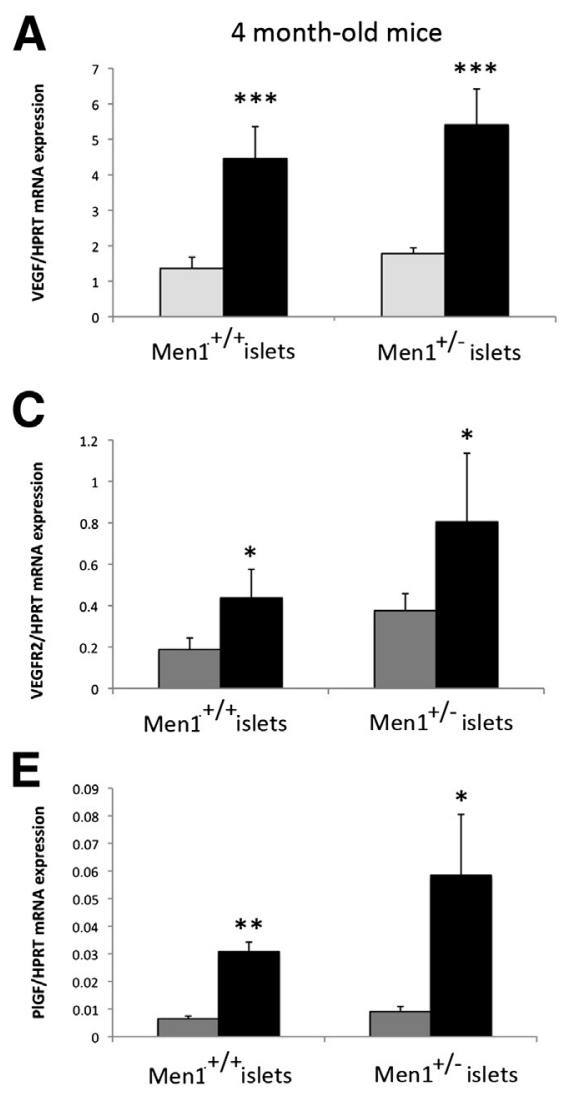

$\square$ Normoxia
$\mathbf{F}$

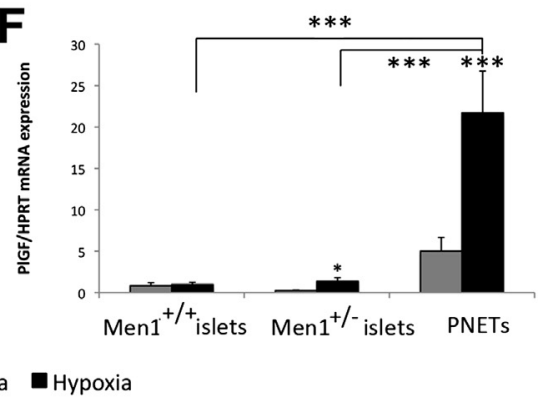

B

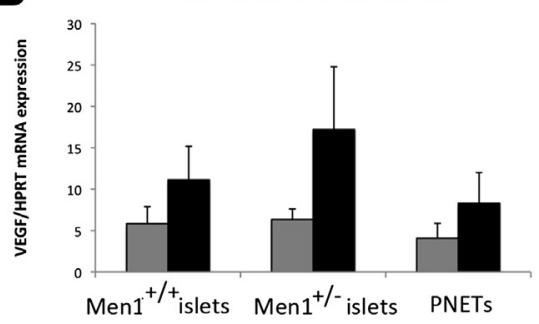

D

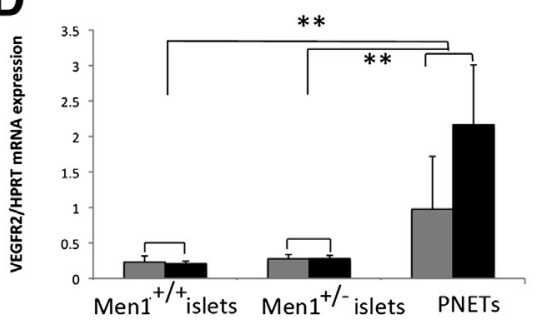

Figure 2 Quantification of mRNA expression Islets isolated from $\mathrm{Men}^{+/+}$and $\mathrm{Men} 1^{+/-}$mice and pancreatic NETs isolated from Men1 $1^{+/-}$mice were cultured for 6 hours under normoxic $\left(20 \% \mathrm{O}_{2}\right)$ or hypoxic $\left(1 \% \mathrm{O}_{2}\right)$ conditions. mRNA expression was then analyzed for VEGF-A (A), VEGFR2 (C), and PIGF (E) genes in islets isolated from young $M e n 1^{+/+}$and Men $1^{+/-}$mice and for the same genes in islets isolated from the older Men1 $1^{+/+}$ and $M e n 1^{+/-}$mice and in pancreatic NETs isolated from the older Men1 ${ }^{+/-}$mice [VEGF-A (B), VEGFR2 (D), and PLGF (F)]. Data are expressed as means \pm SEM. ${ }^{*} P<0.05,{ }^{* *} P<0.01$, and ${ }^{* * *} P<0.001$ versus normoxic control $(\mathbf{A}, \mathbf{C}$, and $\mathbf{E})$ or as indicated by bracketing ( $\mathbf{E}$ and $\mathbf{F}$ ), two-way analysis of variance and Bonferroni's post hoc test. levels of genes from the VEGF signaling pathway.
(Figure 6). Moreover, pericytes of the $M e n 1^{+/+}$islets displayed a peripheral location in close association with islet capillaries, whereas in $\mathrm{Menl}^{+/-}$islets the NG2-positive pericytes were evenly distributed throughout the islet core, many of them showing no contact with or vicinity to islet endothelium (Figure 6). Immunofluorescence examination of Men1 mouse pancreatic NETs revealed a significantly lower abundance of pericytes, which occasionally formed glomerular structures partly embedding the supporting endothelial cells (Figure 6).
A

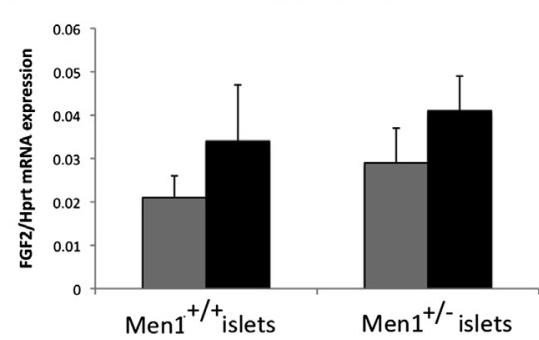

C

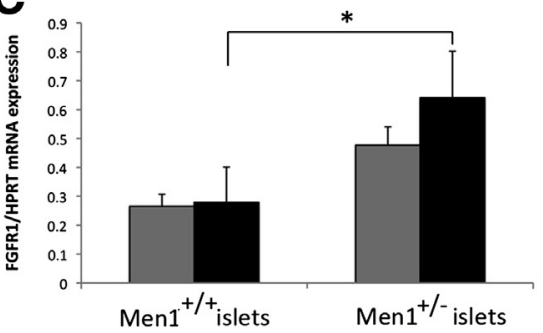

B

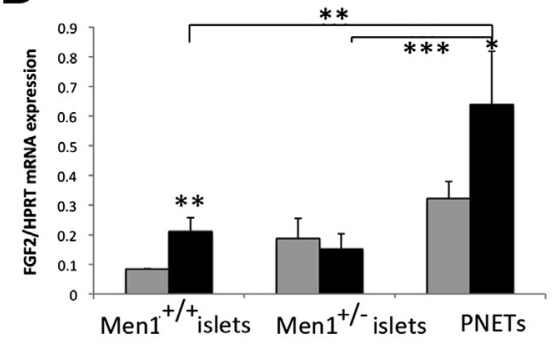

D

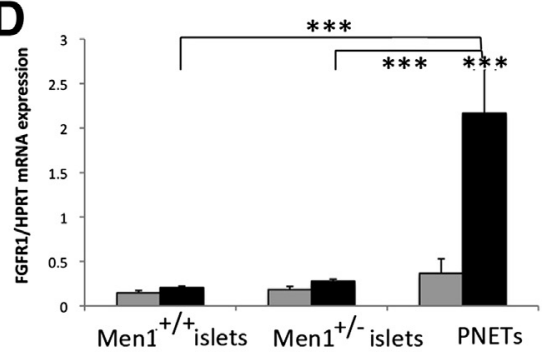

Figure 3 Quantification of mRNA expression levels of genes from the FGF signaling pathway. Islets isolated from $\mathrm{Men1}^{+/+}$and Men1 ${ }^{+/-}$mice and pancreatic NETs isolated from Men1 $1^{+/-}$mice were cultured for 6 hours under normoxic $\left(20 \% \mathrm{O}_{2}\right)$ or hypoxic $\left(1 \% \mathrm{O}_{2}\right)$ conditions. mRNA expression was then analyzed for FGF2 (A) and FGFR1 (C) genes in islets isolated from young $M e n 1^{+/+}$and $\mathrm{Men1}^{+/-}$mice and for the same genes in islets isolated from the older Men1 $1^{+/+}$and $\mathrm{Men}^{+/-}$ mice and in pancreatic NETs isolated from the older Men1 ${ }^{+/-}$mice [FGF2 (B) and FGFR1 (D)]. Data are expressed as means \pm SEM. ${ }^{*} P<0.05,{ }^{*} P P<$ 0.01 , and $* * * P<0.001$ versus normoxic control (A and $\mathbf{C}$ ) or as indicated by bracketing (B and $\mathbf{D})$, two-way analysis of variance and Bonferroni's post hoc test. 


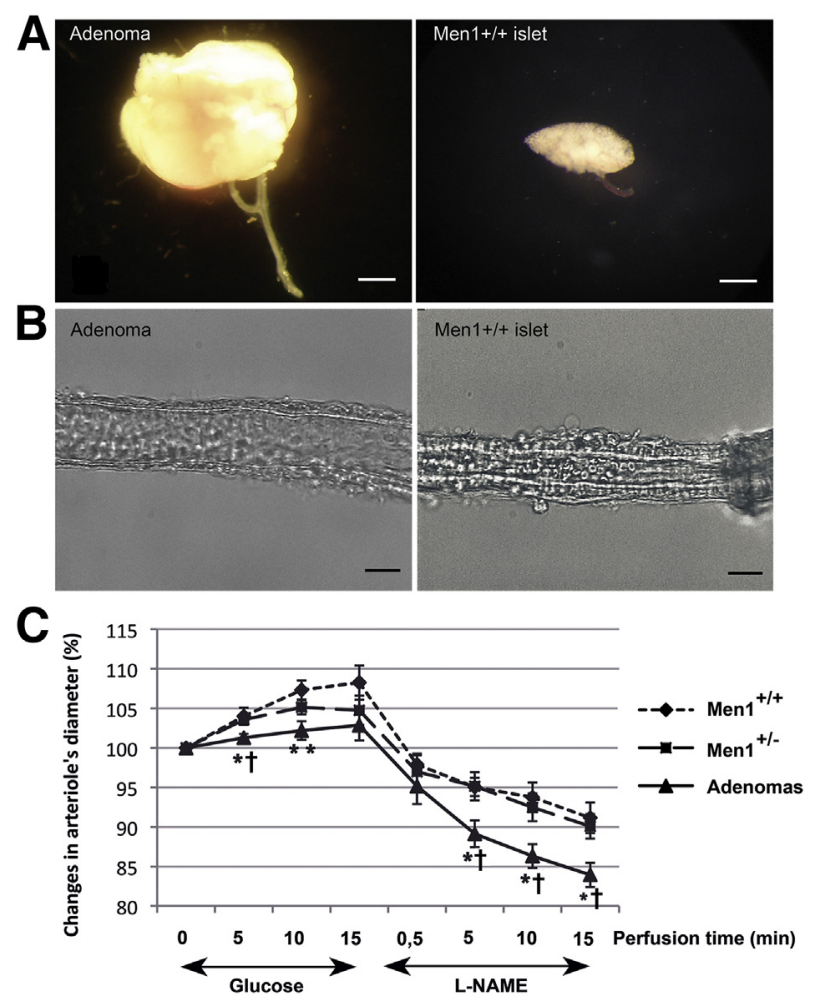

Figure 4 Altered vascular reactivity of islet and tumor arterioles of Men $1^{+/-}$mice. A: Islets from Men1 $1^{+/+}$and $M e n 1^{+/-}$mice and pancreatic NETs (adenoma) from Men1 ${ }^{+/-}$mice were microdissected with their arterioles intact under a stereomicroscope. On the stage of an inverted microscope, a pipette was used to keep the islet in place and another pipette was used to perfuse the end of the microdissected arteriole. B: Micrographs of a tumor arteriole and an islet arteriole as seen through the inverted microscope during the perfusion experiments. C: Changes in diameter of islet arterioles isolated from $\mathrm{Men}^{+/+}$and $\mathrm{Men} 1^{+/-}$mice and of arterioles supplying pancreatic NETs (adenomas) in $\mathrm{Men}^{+/-}$mice, induced by perfusion with KRBH buffer supplemented with $17 \mathrm{mmol} / \mathrm{L} \mathrm{D}$ glucose or $0.1 \mathrm{mmol} / \mathrm{L}$ L-NAME. The islet or tumor diameter under basal conditions (ie, perfused with KRBH buffer) was set as $100 \%$. Data are expressed as means \pm SEM. ${ }^{*} P<0.05,{ }^{* *} P<0.01$ versus Men $1^{+/+}$islet arterioles; ${ }^{\dagger} P<0.05$ versus Men $1^{+/-}$islet arterioles, two-way analysis of variance and Bonferroni's post hoc test. Scale bars: $100 \mu \mathrm{m}(\mathbf{A}) ; 30 \mathrm{~nm}(\mathbf{B})$.

\section{Differential mRNA Expression of Several Factors Involved in Vessel Stabilization}

We observed a significant increased expression of PDGF-BB and PDGFR- $\beta$ mRNA in islets isolated from $\mathrm{Men} \mathrm{I}^{+/-}$young mice, compared with their $M e n 1^{+/+}$controls (1.9-fold increase and 3-fold increase for PDGF-BB and PDGFR- $\beta$, respectively) (Figure 7, A and C). These differences were significantly higher in isolated pancreatic NETs cultured under normoxic conditions (17-fold increased PDGF-BB mRNA expression and 7-fold increased PDGFR- $\beta$ mRNA expression in pancreatic NETs versus $M e n 1^{+/-}$islets) and were further modulated by hypoxia to a 24 -fold increase in PDGF-BB mRNA expression and a 19-fold increase in PDGFR- $\beta$ (Figure 7, B and D).

The mRNA expression of angiopoietins 1 and 2 and their receptors Tie2 (and Tie1; data not shown) was not different in the endocrine tissues of young $\mathrm{Men1^{+/- }}$ mice, compared with their age-matched controls (Figure 8, A, C, and E). However, pancreatic NETs isolated from $\mathrm{MenI}^{+/-}$mice displayed a significantly increased mRNA expression for both Ang-2 (13-fold increase) and Tie2 (18-fold increase) in pancreatic NETs, compared with $\mathrm{MenI}^{+/-}$islets. Ang-2 mRNA expression was further modulated under hypoxic conditions, with up to a 37 -fold increase in pancreatic NETs, compared with normal islets isolated from the same MenI $^{+/-}$mice (Figure 8, B, D, and F).

\section{Angiogenic Protein Expression in $M e n 1^{+/-}$Islets and Pancreatic NETs}

As assessed by immunohistochemistry, VEGF-A, FGF2, FGFR1, PDGF-B, Ang-1, and Ang-2 expression was widely and uniformly distributed in the islets of both $\mathrm{MenI^{+/+ }}$ and $M e n 1^{+/-}$mice (Figure 9A), exhibiting a slightly stronger immunoreactivity in islets of the $M e n 1^{+/-}$mice. All of these angiogenic factors were also expressed in all tumoral lesions of the older $\mathrm{MenI}^{+/-}$mice, independent of their hormonal production, with the exception of FGF2, which was present only in the insulin-positive endocrine cells. A striking heterogeneity was observed in the distribution of these
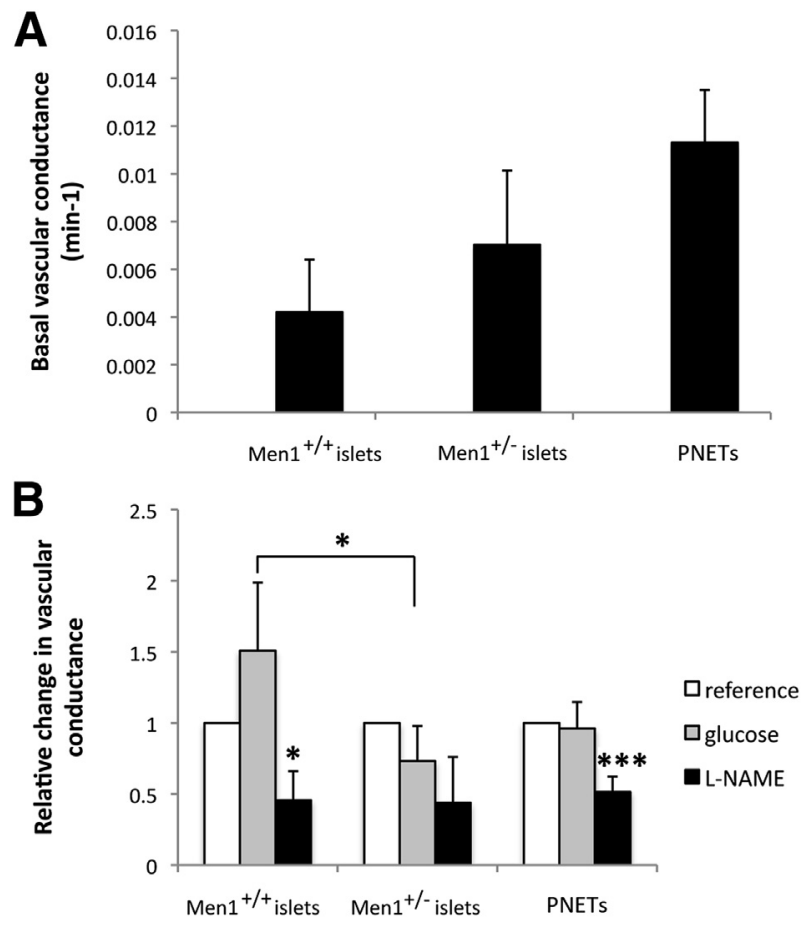

Figure 5 In vivo single-islet and tumor blood perfusion measurements in young $M e n 1^{+/+}$and $M e n 1^{+/-}$mice and in pancreatic NETs of the older Men $1^{+/-}$mice. A: Basal islet conductance as calculated using the hydrogen washout technique. B: Relative changes induced by $2 \mathrm{mg} / \mathrm{g}$ body weight $\mathrm{D}-$ glucose and $25 \mu \mathrm{g} / \mathrm{g}$ body weight L-NAME in islet or tumor vascular conductance. Basal conductance was set at 1 for each group. Data are expressed as means \pm SEM. ${ }^{*} P<0.05,{ }^{* * *} P<0.001$ versus basal conductance or as indicated by bracketing, two-way analysis of variance and Bonferroni's post hoc test. 

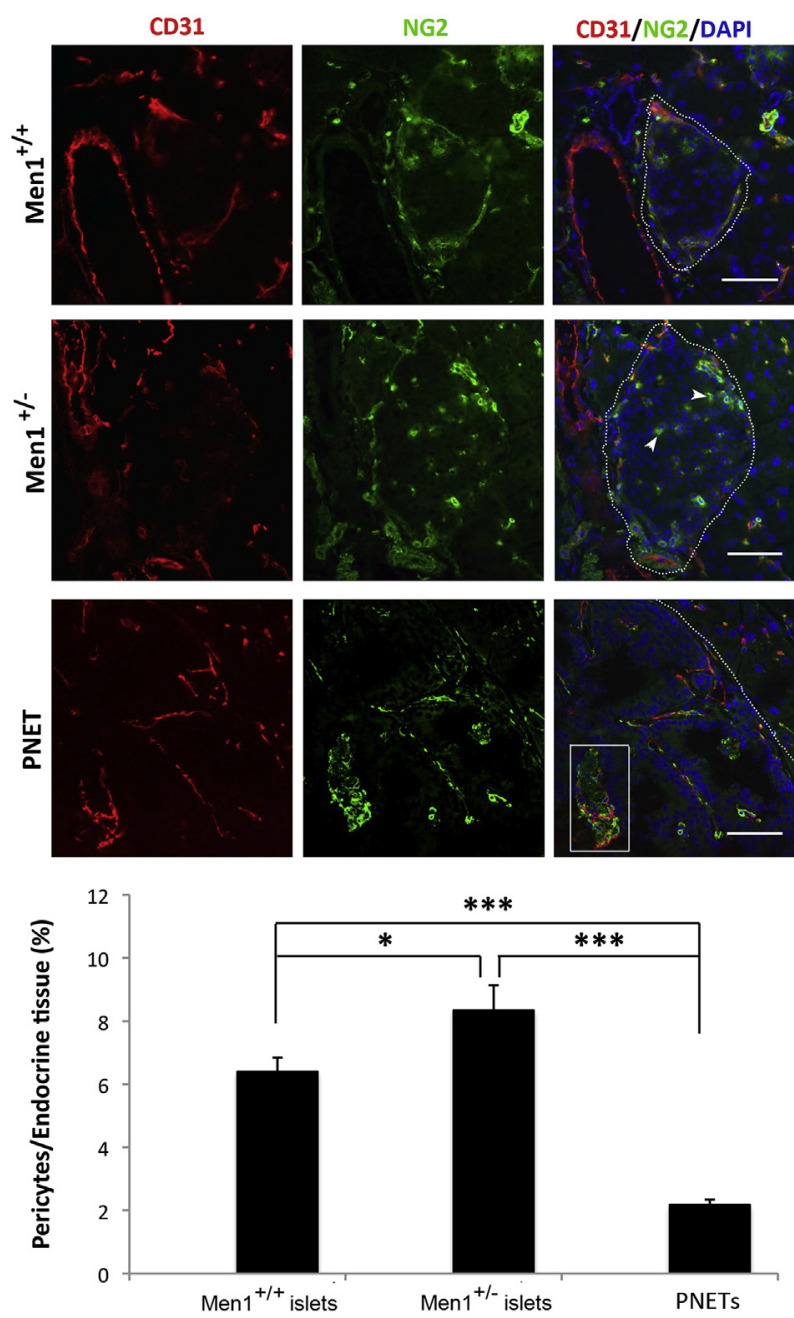

Figure 6 Pericyte distribution in islets and pancreatic NETs of Men1 $1^{+/-}$ mice. Top: Immunofluorescence micrographs show pericyte/endothelial cell association in islets of young $M e n 1^{+/+}$and $M e n 1^{+/-}$mice and in pancreatic NETs of the older Men1 $1^{+/-}$mice. Examples of NG2-immunoreactive pericytes (green) with no direct association to CD31-positive ECs (red) are indicated by arrows. Glomerular-like structures of pericytes are observed within the pancreatic NETs (boxed region). Pancreatic islets/pancreatic NET are indicated with a dotted outline. Bottom: Endothelial pericyte/ endocrine tissue quantification in $M e n 1^{+/+}$endocrine pancreas, Men1 $1^{+/-}$ normal endocrine pancreas, and $M e n 1^{+/-}$pancreatic NETs. Data are expressed as means \pm SEM. ${ }^{*} P<0.05,{ }^{*} * P<0.001$, one-way analysis of variance and Fisher's post hoc test. Scale bar $=100 \mu \mathrm{m}$.

angiogenic factors within pancreatic NETs; strong immunoreactivities for VEGF-A, FGF2, FGFR1, PDGF-B, and Ang-1 overlapped to a great extent with intense staining for HIF- $1 \alpha$ in the endocrine cells of pancreatic lesions, which had already lost nuclear menin expression (Figure 9B).

\section{Discussion}

Normal endocrine tissues and endocrine-derived tumors are characteristically highly vascular and possess a dense and specialized permeable microvascular endothelium. In contrast to other solid malignancies, however, dense vascularization of pancreatic NETs per se does not necessarily correlate with unfavorable prognosis ${ }^{16,17}$ suggesting the existence of regulatory mechanisms unique for this particular type of tumor. In the present study, we sought to uncover the morphological, functional, and molecular abnormalities of endocrine pancreatic tumor vasculature using the Menl mouse model.

We observed significantly increased vascular density, along with several structurally distinct blood vessel changes, in tumoral lesions of the older MenI ${ }^{+/-}$mice, compared with normal endocrine tissue from age-matched controls. Previous studies in other models have demonstrated that some of these vascular structures, such as glomeruloid microvascular proliferations, require continued presence of exogenous VEGFA, whereas other vascular structures (eg, malformations formed by co-option of existing vessels and most probably capillaries) seem to have acquired VEGF-A independence. ${ }^{15}$ Moreover, it has been speculated that such VEGF-Aindependent vessels are most probably long lasting and most likely to become predominant in slow-growing tumors, which is the case both for the pancreatic NETs developed by $M e n I^{+/-}$mice and for human pancreatic NETs. In our model, the aberrant phenotype of the tumor vasculature was paralleled by the activation of the VEGF-A/VEGFR2/PIGF and FGF2/FGFR1 pathways.

The significantly up-regulated levels of VEGFR2 mRNA in $M e n 1^{+/-}$pancreatic NETs reported here support the existence of a sustained activation of the master proangiogenic signaling pathway VEGF-A/VEGFR2. In the RIP-Tag mouse model of endocrine tumorigenesis, VEGFR2 plays a critical role in promoting and sustaining angiogenesis in pancreatic islet cell tumors, and VEGFR2 blockade induces decreased vessel density, decreased vascular permeability, and reduced microhemorrhage. ${ }^{18}$ In the present study, PIGF mRNA expression was also up-regulated in pancreatic NETs, and further potentiated by hypoxic challenge, which supports a previously described contribution to the pathological mechanisms of tumor neovascularization. ${ }^{19}$ Moreover, in the present study we have demonstrated that the FGF2/FGFR1 angiogenic pathway is highly activated in this particular model of endocrine tumorigenesis. In particular, FGFR1 upregulation occurred early in tumor development and reached significance under hypoxic conditions. Given that a role for FGFs in restimulating tumor angiogenesis in a VEGFindependent fashion after anti-VEGFR2 blockade has been suggested in other pancreatic NET models, ${ }^{18}$ and that increased FGF2-like substance in the plasma of subjects with MEN1 has been reported, ${ }^{20,21}$ the present data point to FGF pathways as possible complementary therapeutic targets for treatment of MEN1-related pancreatic NETs. At the protein level, these angiogenic factors were heterogeneously distributed within the endocrine lesions. Thus, strong protein expression areas were overlapping with intense HIF-1 $\alpha$ staining, indicating, together with our molecular results, that activated angiogenic pathways and the expression of hypoxia-regulated proteins are strongly associated with each other in MEN1-related pancreatic NETs. 


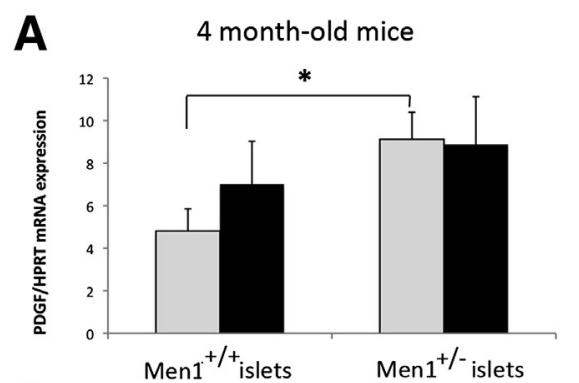

C

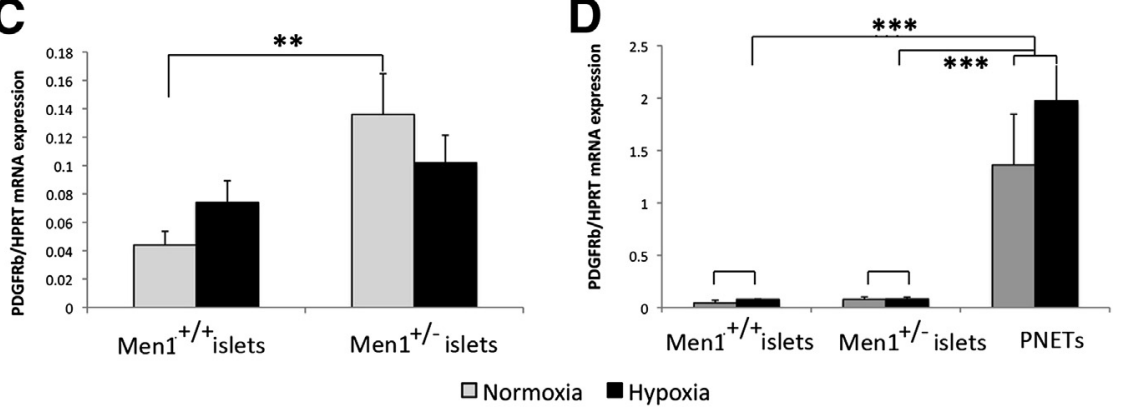

B

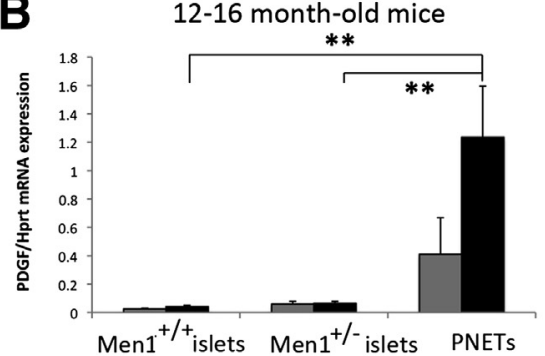

D

Figure 7 Quantification of mRNA expression levels of genes from the PDGF signaling pathway. Islets isolated from Men1 ${ }^{+/+}$and Men1 $1^{+/-}$mice and pancreatic NETs isolated from Men1 $1^{+/-}$mice were cultured for 6 hours under normoxic $\left(20 \% \mathrm{O}_{2}\right)$ or hypoxic $\left(\begin{array}{ll}1 \% \mathrm{O}_{2} \\ )\end{array}\right)$ conditions. mRNA expression was then analyzed for PDGF-BB (A and B) and PDGFR- $\beta$ (C and $\mathbf{D})$ genes in islets isolated from young Men $1^{+/+}$and $M e n 1^{+/-}$mice (A and $\mathbf{C}$ ), in islets isolated from the older Men1 ${ }^{+/+}$and $M e n 1^{+/-}$ mice (B and $\mathbf{D})$, and in pancreatic NETs isolated from the older Men $1^{+/-}$mice (B and $\left.\mathbf{D}\right)$. Data are expressed as means \pm SEM. ${ }^{*} P<0.05,{ }^{*} P P<$ 0.01 , and $* * * P<0.001$, two-way analysis of variance and Bonferroni's post hoc test.

Another major finding of the present study is that morphological aberrations of the tumor vasculature also translate into dramatically altered vascular reactivity and in vivo blood perfusion in response to various physiological triggers. It is well known that islet blood flow is normally coupled to islet insulin release, ${ }^{22}$ and that the association seems to be dependent on an intact production of NO within the islet vasculature. ${ }^{23}$ We therefore investigated the vasomodulatory effects of D-glucose, the main insulin secretagogue, and of L-NAME, a potent NO synthase (NOS) inhibitor. Islet blood flow is 5 to 10 times higher than the blood flow of the exocrine pancreas, ${ }^{22,24}$ and this differential blood perfusion is maintained by separate regulatory mechanisms for the islets and the acini. The single-islet and tumor

\section{A}

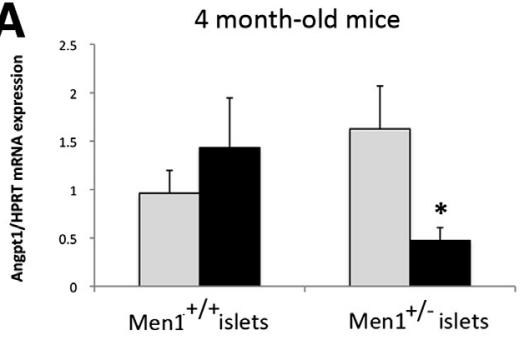

C

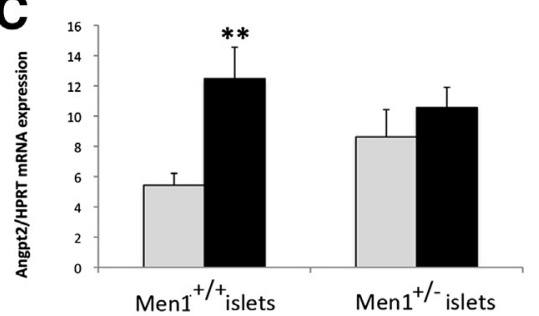

E

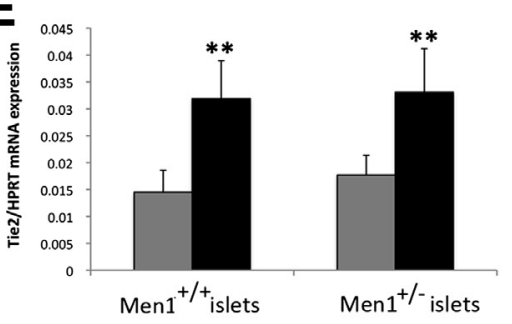

B

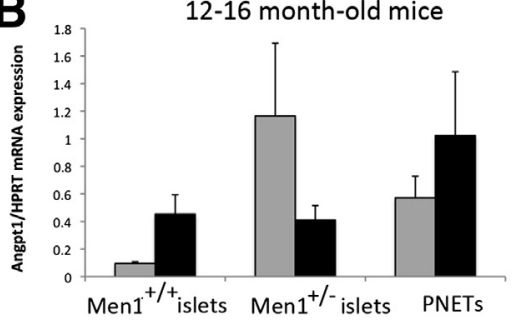

D

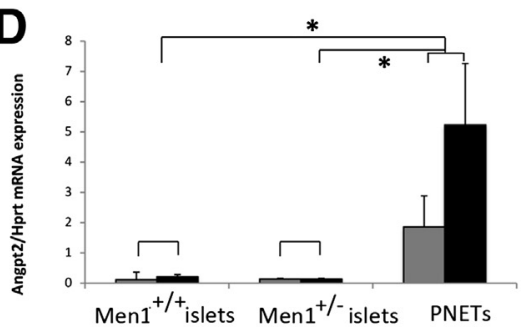

F

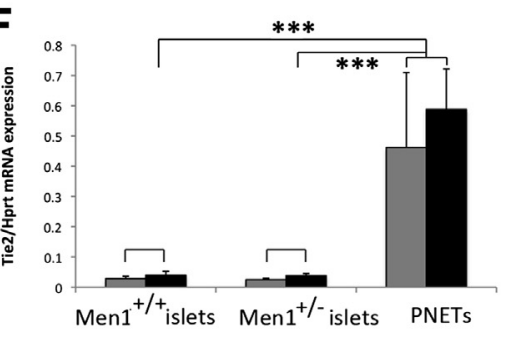

Figure 8 Quantification of mRNA expression levels of genes from the angiopoietin signaling pathway. Islets isolated from Men1 $1^{+/+}$and Men1 $1^{+/-}$ mice and adenomas isolated from $\mathrm{Men1}^{+/-}$mice were cultured for 6 hours under normoxic $\left(20 \% \mathrm{O}_{2}\right)$ or hypoxic $\left(1 \% \mathrm{O}_{2}\right)$ conditions. mRNA expression was then analyzed for Ang-1 (A and $\mathbf{B})$, Ang-2 ( $\mathbf{C}$ and $\mathbf{D})$, and Tie2 (E and $\mathbf{F})$ genes in islets isolated from young Men1 $1^{+/+}$and Men1 $1^{+/-}$mice $(\mathbf{A}, \mathbf{C}$, and $\mathbf{E})$, in islets isolated from the older Men1 ${ }^{+/+}$and $M e n 1^{+/-}$ mice (B, D, and $\mathbf{F}$ ), and in pancreatic NETs isolated from the older Men1 ${ }^{+/-}$mice $(\mathbf{B}, \mathbf{D}$, and $\mathbf{F})$. Data are expressed as means \pm SEM. ${ }^{*} P<0.05,{ }^{* *} P<0.01$, and ${ }^{* * *} P<0.001$ versus normoxic control (A, $\mathbf{C}$, and $\mathbf{E}$ ) or as indicated by bracketing ( $\mathbf{D}$ and $\mathbf{F})$, twoway analysis of variance and Bonferroni's post hoc test. 


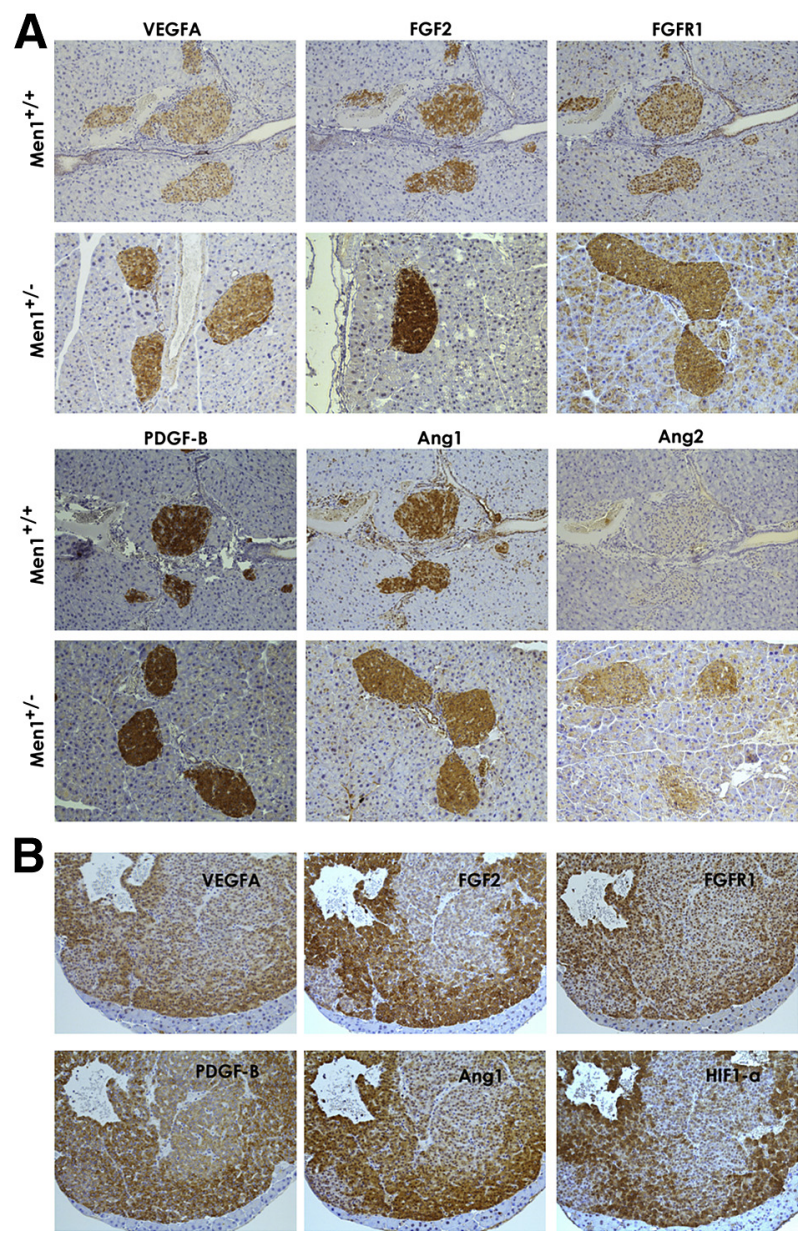

Figure 9 Representative micrographs of islets of young $M e n 1^{+/+}$and Men $1^{+/-}$mice (A) and pancreatic NETs of the older Men $1^{+/-}$mice (B) immunoreactive for VEGF-A, FGF2, FGFR1, PDGF-B, Ang-1, Ang-2, and HIF- $1 \alpha$. Original magnification, $\times 20$.

perfusion technique used here enabled us to specifically study the reactivity of islet and tumor arterioles in an ex vivo setting, without any confounding factors imposed by systemic vascular effects or from blood vessels supplying the exocrine parenchyma. ${ }^{12}$ Moreover, we have further supported our ex vivo data with in vivo blood perfusion measurements in single islets/pancreatic NETs, using, for the first time in such a setting, a recently adapted hydrogen gas clearance-based technique. We show here that the blood flow to pancreatic NETs is differentially regulated, that the control mechanism seems to occur at the precapillary level, similar to normal pancreatic islets, ${ }^{12}$ and that relatively moderate variations in vascular adaptive response promote a significant functional impairment. Our observations thus raise the intriguing possibility of exploiting this particular feature to improve cancer treatment.

In our model, glucose exerted a pronounced dilating effect on the islet arterioles, as previously reported, ${ }^{12}$ and was paralleled, as expected, by an increased islet blood flow in vivo. Interestingly, the potency of vascular responses to high glucose levels, as well as the corresponding in vivo blood perfusion, was significantly attenuated in isolated tumor capillaries and in $\mathrm{Menl}^{+/-}$islet vessels. Several regulatory mechanisms modulating preferentially islet blood flow after glucose challenge have been proposed. In vivo, these include induction of vasodilation by the central nervous system, ${ }^{25}$ up-regulation of inducible NOS and constitutive NO release as a result of the islets metabolic demand of oxygen, ${ }^{26}$ or adenosine production associated with islet metabolism. ${ }^{27}$ Whether one or several of these mechanisms are involved in the altered glucose-induced vascular reactivity of the isolated $\mathrm{MenI} \mathrm{I}^{+/-}$islet and tumor arterioles remains to be determined. However, the present study demonstrated that administration of L-NAME, a potent NOS inhibitor, significantly impaired blood perfusion in islets and pancreatic NETs and induced a more pronounced constriction of the tumor-supplying arterioles, suggesting that the tumor arterioles are more sensitive than normal islet vasculature to the effects and/or production of NO.

In normal pancreatic islets, both endothelial cells and $\beta$ cells are able to produce $\mathrm{NO},{ }^{28,29}$ inducing changes in mural cells and thus allowing for the local control of blood flow. In particular, pericytes are putative candidates because they can induce vessel constriction and modify vascular diameter. ${ }^{30}$ Consistent with previous reports, ${ }^{31,32}$ we have observed a sparse presence of pericytes in the normal islets, localized mostly in the periphery. This distribution was significantly altered in $\mathrm{MenI}^{+/-}$endocrine pancreatic tissue, in which we found frequent NG2-immunoreactive cells in the islet core and a heterogeneous coverage of pericytes on the vascular structures of the pancreatic NETs. Because a single pericyte often contacts several endothelial cells, it may facilitate and integrate functional longitudinal communications from arterioles down to capillaries and back, providing pathways for both short-term modulation of diameter and long-term regulation of the microvascular network architecture in physiological and pathological conditions. ${ }^{33}$ By similar mechanisms, therefore, the altered pericyte distribution reported here could contribute to the aberrant adaptive vascular responses and to the decreased in vivo blood perfusion after glucose challenge, as well as to the increased sensitivity of tumor-supporting arterioles to $\mathrm{NO}$ production.

Previous studies have demonstrated that pericyte recruitment in developmental angiogenesis depends on endothelium-derived PDGF-BB and pericytic expression of PDGFR- $\beta .{ }^{34,35}$ Moreover, in pathological angiogenesis, both PDGF-BB ${ }^{36}$ and PDGFR- $\beta^{37}$ expression stimulates pericyte recruitment in gliomas or insulinomas, respectively. The significantly increased expression of PDGF-BB and PDGFR$\beta$ observed in the present study supports a role for this particular pathway in endocrine pancreatic MEN1 tumorigenesis and thus provides a possible explanation for the disturbed distribution of pericytes in the islets and pancreatic NETs of our model. Furthermore, the observed up-regulation of PDGF-BB and PDGFR- $\beta$ early in the normal MenI $1^{+/-}$ endocrine pancreas suggest a possible mechanism by which 
their expression might be modulated by menin levels already in the pancreatic endocrine tissue of young $\mathrm{MenI}^{+/-}$mice.

Ang-1/Ang-2-Tie2 is another deregulated molecular pathway previously shown to be involved in vascular stabilization. The traditional view of Ang-1 and Ang-2 signaling is that the growth factors mediate opposite effects on Tie2 receptor activation, in that Ang-1 binds to Tie2 to promote vascular maturation and integrity, whereas Ang-2 acts as a naturally occurring antagonist of Ang- $1 .^{38-40}$ Additionally, recent studies attribute to Ang-2 a potent proangiogenic role, dependent on the concurrent availability of VEGF. ${ }^{41-43}$ Given that endocrine pancreatic cells produce high levels of VEGF and are therefore capable of supplying this required growth factor environment, it is likely that activation of Ang$2 /$ Tie2 signaling promotes a proangiogenic process in our model, but can also provide a mechanism for the decreased pericyte distribution observed in the pancreatic NETs of Men1 mice.

Here, we have shown that the pancreatic NETs developed in the Menl mouse model are associated with differential modulation of several angiogenic genes. A direct functional relationship between these factors and menin is yet to be determined. However, based on our data and considering previous functional studies unveiling menin roles in transcriptional regulation, we can speculate on a causal relation between decreased levels of menin and modulation of these angiogenic molecules, via multiple signaling pathways. It is documented that menin potently down-regulates Akt and its kinase activity, ${ }^{44}$ which are essential for maintenance of increased expression of VEGF-A,${ }^{45}$ FGF $2,{ }^{46}$ and PDGF and PDGFR $-\beta^{47}$ in several other models of tumor development. Menin can also modulate transcription indirectly by regulating $\beta$-catenin subcellular localization; menin deficiency causes accumulation of $\beta$-catenin in the nucleus and subsequent transcriptional activation of its targeted genes, such as VEGF-A in colon cancer cells ${ }^{48}$ and FGF2 via HOXA10 activation in myeloid cells. ${ }^{49,50}$ Moreover, menin has also been shown to interact with and to regulate gene tran-

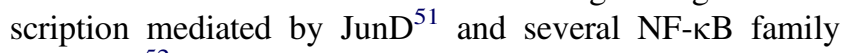
members, ${ }^{52}$ and these pathways constitute additional mechanisms by which menin deficiency may modulate specific angiogenic signals. Further molecular studies are needed to more exactly elucidate functional relationships between menin and these factors in vitro, and the significance of these molecular pathways in contributing to tumor development in this particular model needs to be further validated in vivo using specific inhibitors.

In summary, the morphological, physiological, and molecular data presented here provide descriptive and functional indications for a significantly altered architecture and reactivity of the vasculature of pancreatic NETs in $M e n 1^{+/-}$ mice. Using a novel single-islet and tumor perfusion technique, we could demonstrate that the vascular contractile responses to vasoactive agents in tumor- and normal isletsupplying capillaries are differentially regulated. At the molecular level, these vascular aberrations seem to be supported by differential expression of multiple angiogenic factors. Our data demonstrate that several of them (ie, FGF2/ FGFR1 and PDGF-B/PDGFR- $\beta$ ) are already turned on in microscopically normal endocrine tissue of $\mathrm{MenI}^{+/-}$mice. Further in vivo studies are warranted to investigate whether these early events are an expression of an initial vasculopathy preceding tumor formation or whether they reflect a haploinsufficient role of menin in MEN1-related pancreatic tumorigenesis.

\section{Acknowledgments}

We thank Prof. Erik Persson for providing valuable expertise on the single-islet and tumor perfusion technique and Anette von Malborg and Anna Norling for skilled technical assistance.

\section{References}

1. Singh RP, Agarwal R: Tumor angiogenesis: a potential target in cancer control by phytochemicals. Curr Cancer Drug Targets 2003, 3: 205-217

2. Weidner N, Folkman J, Pozza F, Bevilacqua P, Allred EN, Moore DH, Meli S, Gasparini G: Tumor angiogenesis: a new significant and independent prognostic indicator in early-stage breast carcinoma. J Natl Cancer Inst 1992, 84:1875-1887

3. Vermeulen PB, Verhoeven D, Hubens G, Van Marck E, Goovaerts G, Huyghe M, De Bruijn EA, Van Oosterom AT, Dirix LY: Microvessel density, endothelial cell proliferation and tumour cell proliferation in human colorectal adenocarcinomas. Ann Oncol 1995, 6:59-64

4. Ellis LM, Takahashi Y, Fenoglio CJ, Cleary KR, Bucana CD, Evans DB: Vessel counts and vascular endothelial growth factor expression in pancreatic adenocarcinoma. Eur J Cancer 1998, 34:337-340

5. Duarte IG, Bufkin BL, Pennington MF, Gal AA, Cohen C, Kosinski AS, Mansour KA, Miller JI: Angiogenesis as a predictor of survival after surgical resection for stage I non-small-cell lung cancer. J Thorac Cardiovasc Surg 1998, 115:652-658; discussion 658-659

6. d'Assignies G, Couvelard A, Bahrami S, Vullierme MP, Hammel P, Hentic O, Sauvanet A, Bedossa P, Ruszniewski P, Vilgrain V: Pancreatic endocrine tumors: tumor blood flow assessed with perfusion CT reflects angiogenesis and correlates with prognostic factors. Radiology 2009, 250:407-416

7. Takahashi Y, Akishima-Fukasawa Y, Kobayashi N, Sano T, Kosuge T, Nimura Y, Kanai Y, Hiraoka N: Prognostic value of tumor architecture, tumor-associated vascular characteristics, and expression of angiogenic molecules in pancreatic endocrine tumors. Clin Cancer Res 2007, 13:187-196

8. Brandi ML, Gagel RF, Angeli A, Bilezikian JP, Beck-Peccoz P, Bordi C, Conte-Devolx B, Falchetti A, Gheri RG, Libroia A, Lips CJ, Lombardi G, Mannelli M, Pacini F, Ponder BA, Raue F, Skogseid B, Tamburrano G, Thakker RV, Thompson NW, Tomassetti P, Tonelli F, Wells SA Jr., Marx SJ: Guidelines for diagnosis and therapy of MEN type 1 and type 2. J Clin Endocrinol Metab 2001, 86:5658-5671

9. Doherty GM: Multiple endocrine neoplasia type 1: duodenopancreatic tumors. Surg Oncol 2003, 12:135-143

10. Loffler KA, Biondi CA, Gartside M, Waring P, Stark M, SerewkoAuret MM, Muller HK, Hayward NK, Kay GF: Broad tumor spectrum in a mouse model of multiple endocrine neoplasia type 1 . Int $\mathbf{J}$ Cancer 2007, 120:259-267

11. Andersson A: Isolated mouse pancreatic islets in culture: effects of serum and different culture media on the insulin production of the islets. Diabetologia 1978, 14:397-404 
12. Lai EY, Jansson L, Patzak A, Persson AE: Vascular reactivity in arterioles from normal and alloxan-diabetic mice: studies on single perfused islets. Diabetes 2007, 56:107-112

13. Aukland K, Wolgast M: Effect of hemorrhage and retransfusion on intrarenal distribution of blood flow in dogs. J Clin Invest 1968, 47: 488-501

14. Liss P, Aukland K, Carlsson PO, Palm F, Hansell P: Influence of iothalamate on renal medullary perfusion and oxygenation in the rat. Acta Radiol 2005, 46:823-829

15. Nagy JA, Chang SH, Shih SC, Dvorak AM, Dvorak HF: Heterogeneity of the tumor vasculature. Semin Thromb Hemost 2010, 36:321-331

16. Marion-Audibert AM, Barel C, Gouysse G, Dumortier J, Pilleul F, Pourreyron C, Hervieu V, Poncet G, Lombard-Bohas C, Chayvialle JA, Partensky C, Scoazec JY: Low microvessel density is an unfavorable histoprognostic factor in pancreatic endocrine tumors. Gastroenterology 2003, 125:1094-1104

17. Couvelard A, O'Toole D, Turley H, Leek R, Sauvanet A, Degott C, Ruszniewski P, Belghiti J, Harris AL, Gatter K, Pezzella F: Microvascular density and hypoxia-inducible factor pathway in pancreatic endocrine tumours: negative correlation of microvascular density and VEGF expression with tumour progression. Br J Cancer 2005, 92 : 94-101

18. Casanovas O, Hicklin DJ, Bergers G, Hanahan D: Drug resistance by evasion of antiangiogenic targeting of VEGF signaling in late-stage pancreatic islet tumors. Cancer Cell 2005, 8:299-309

19. Fischer C, Jonckx B, Mazzone M, Zacchigna S, Loges S, Pattarini L, Chorianopoulos E, Liesenborghs L, Koch M, De Mol M, Autiero M, Wyns S, Plaisance S, Moons L, van Rooijen N, Giacca M, Stassen JM, Dewerchin M, Collen D, Carmeliet P: Anti-PIGF inhibits growth of $\operatorname{VEGF(R)-inhibitor-resistant~tumors~without~affecting~}$ healthy vessels. Cell 2007, 131:463-475

20. Zimering MB, Katsumata N, Friesen HG, Eng J, Riley DJ, ThakkerVaria S, Marx SJ, Ezzat S: Fibroblast growth factor-like autoantibodies in plasma from patients with multiple endocrine neoplasia type 1 and prolactinoma. Ann N Y Acad Sci 1997, 815:520-523

21. Komatsu M, Tsuchiya S, Matsuyama I, Kaneko S, Suzuki Y, Ito N, Hanamura N, Seki T, Kobayashi S, Kuroda T: Expression of basic fibroblast growth factor in hyperplastic parathyroid glands from patients with multiple endocrine neoplasia type I. World J Surg 1994, 18:921-924; discussion 925

22. Brunicardi FC, Stagner J, Bonner-Weir S, Wayland H, Kleinman R, Livingston E, Guth P, Menger M, McCuskey R, Intaglietta M, Charles A, Ashley S, Cheung A, Ipp E, Gilman S, Howard T, Passaro E Jr.: Microcirculation of the islets of Langerhans. Long Beach Veterans Administration Regional Medical Education Center Symposium. Diabetes 1996, 45:385-392

23. Svensson AM, Ostenson CG, Sandler S, Efendic S, Jansson L: Inhibition of nitric oxide synthase by NG-nitro-L-arginine causes a preferential decrease in pancreatic islet blood flow in normal rats and spontaneously diabetic GK rats. Endocrinology 1994, 135: 849-853

24. Jansson L: The regulation of pancreatic islet blood flow. Diabetes Metab Rev 1994, 10:407-416

25. Carlsson PO, Iwase M, Jansson L: Stimulation of intestinal glucoreceptors in rats increases pancreatic islet blood flow through vagal mechanisms. Am J Physiol 1999, 276:R233-R236

26. Jansson L, Hellerström C: Stimulation by glucose of the blood flow to the pancreatic islets of the rat. Diabetologia 1983, 25:45-50

27. Carlsson PO, Olsson R, Källskog O, Bodin B, Andersson A, Jansson L: Glucose-induced islet blood flow increase in rats: interaction between nervous and metabolic mediators. Am J Physiol Endocrinol Metab 2002, 283:E457-E464

28. Corbett JA, Wang JL, Sweetland MA, Lancaster JR Jr., McDaniel ML: Interleukin 1 beta induces the formation of nitric oxide by beta-cells purified from rodent islets of Langerhans. Evidence for the beta-cell as a source and site of action of nitric oxide. J Clin Invest 1992, 90:2384-2391
29. Corbett JA, Wang JL, Hughes JH, Wolf BA, Sweetland MA, Lancaster JR Jr., McDaniel ML: Nitric oxide and cyclic GMP formation induced by interleukin 1 beta in islets of Langerhans. Evidence for an effector role of nitric oxide in islet dysfunction. Biochem J 1992, 287:229-235

30. Peppiatt CM, Howarth C, Mobbs P, Attwell D: Bidirectional control of CNS capillary diameter by pericytes. Nature 2006, 443:700-704

31. Nakamura M, Kitamura H, Konishi S, Nishimura M, Ono J, Ina K, Shimada T, Takaki R: The endocrine pancreas of spontaneously diabetic $\mathrm{db} / \mathrm{db}$ mice: microangiopathy as revealed by transmission electron microscopy. Diabetes Res Clin Pract 1995, 30:89-100

32. Richards OC, Raines SM, Attie AD: The role of blood vessels, endothelial cells, and vascular pericytes in insulin secretion and peripheral insulin action. Endocr Rev 2010, 31:343-363

33. Figueroa XF, Duling BR: Gap junctions in the control of vascular function. Antioxid Redox Signal 2009, 11:251-266

34. Lindahl P, Johansson BR, Levéen P, Betsholtz C: Pericyte loss and microaneurysm formation in PDGF-B-deficient mice. Science 1997, 277:242-245

35. Hellström M, Kalén M, Lindahl P, Abramsson A, Betsholtz C: Role of PDGF-B and PDGFR-beta in recruitment of vascular smooth muscle cells and pericytes during embryonic blood vessel formation in the mouse. Development 1999, 126:3047-3055

36. Guo P, Hu B, Gu W, Xu L, Wang D, Huang HJ, Cavenee WK, Cheng SY: Platelet-derived growth factor-B enhances glioma angiogenesis by stimulating vascular endothelial growth factor expression in tumor endothelia and by promoting pericyte recruitment. Am J Pathol 2003, 162:1083-1093

37. Bergers G, Song S, Meyer-Morse N, Bergsland E, Hanahan D: Benefits of targeting both pericytes and endothelial cells in the tumor vasculature with kinase inhibitors. J Clin Invest 2003, 111: 1287-1295

38. Holash J, Wiegand SJ, Yancopoulos GD: New model of tumor angiogenesis: dynamic balance between vessel regression and growth mediated by angiopoietins and VEGF. Oncogene 1999, 18: 5356-5362

39. Kim KE, Cho CH, Kim HZ, Baluk P, McDonald DM, Koh GY: In vivo actions of angiopoietins on quiescent and remodeling blood and lymphatic vessels in mouse airways and skin. Arterioscler Thromb Vasc Biol 2007, 27:564-570

40. Maisonpierre PC, Suri C, Jones PF, Bartunkova S, Wiegand SJ, Radziejewski C, Compton D, McClain J, Aldrich TH, Papadopoulos N, Daly TJ, Davis S, Sato TN, Yancopoulos GD: Angiopoietin-2, a natural antagonist for Tie2 that disrupts in vivo angiogenesis. Science 1997, 277:55-60

41. Lobov IB, Brooks PC, Lang RA: Angiopoietin-2 displays VEGFdependent modulation of capillary structure and endothelial cell survival in vivo. Proc Natl Acad Sci USA 2002, 99:11205-11210

42. Visconti RP, Richardson CD, Sato TN: Orchestration of angiogenesis and arteriovenous contribution by angiopoietins and vascular endothelial growth factor (VEGF). Proc Natl Acad Sci USA 2002, 99: 8219-8224

43. Detjen KM, Rieke S, Deters A, Schulz P, Rexin A, Vollmer S, Hauff P, Wiedenmann B, Pavel M, Scholz A: Angiopoietin-2 promotes disease progression of neuroendocrine tumors. Clin Cancer Res 2010, 16:420-429

44. Wang Y, Ozawa A, Zaman S, Prasad NB, Chandrasekharappa SC, Agarwal SK, Marx SJ: The tumor suppressor protein menin inhibits AKT activation by regulating its cellular localization. Cancer Res 2011, 71:371-382

45. Hong SW, Jung KH, Lee HS, Choi MJ, Son MK, Zheng HM, Hong SS: SB365 inhibits angiogenesis and induces apoptosis of hepatocellular carcinoma through modulation of PI3K/Akt/mTOR signaling pathway. Cancer Sci 2012, 103:1929-1937

46. Tsubaki M, Yamazoe Y, Yanae M, Satou T, Itoh T, Kaneko J, Kidera Y, Moriyama K, Nishida S: Blockade of the Ras/MEK/ERK and Ras/PI3K/Akt pathways by statins reduces the expression of 
bFGF, HGF, and TGF-beta as angiogenic factors in mouse osteosarcoma. Cytokine 2011, 54:100-107

47. Conley-LaComb MK, Huang W, Wang S, Shi D, Jung YS, Najy A, Fridman R, Bonfil RD, Cher ML, Chen YQ, Kim HR: PTEN regulates PDGF ligand switch for beta-PDGFR signaling in prostate cancer. Am J Pathol 2012, 180:1017-1027

48. Hwang I, Kim J, Jeong S: beta-Catenin and Peroxisome Proliferator Activated receptor-delta coordinate dynamic chromatin loops for the transcription of VEGFA gene in colon cancer cells. J Biol Chem 2012, 287:41364-41373

49. Shah CA, Bei L, Wang H, Platanias LC, Eklund EA: HoxA10 protein regulates transcription of gene encoding fibroblast growth factor 2 (FGF2) in myeloid cells. J Biol Chem 2012, 287:18230-18248
50. Bei L, Shah C, Wang H, Huang W, Roy R, Eklund EA: Beta-catenin activates the HOXA10 and CDX4 genes in myeloid progenitor cells. J Biol Chem 2012, 287:39589-39601

51. Agarwal SK, Guru SC, Heppner C, Erdos MR, Collins RM, Park SY, Saggar S, Chandrasekharappa SC, Collins FS, Spiegel AM, Marx SJ, Burns AL: Menin interacts with the AP1 transcription factor JunD and represses JunD-activated transcription. Cell 1999 , 96:143-152

52. Heppner C, Bilimoria KY, Agarwal SK, Kester M, Whitty LJ, Guru SC, Chandrasekharappa SC, Collins FS, Spiegel AM, Marx SJ, Burns AL: The tumor suppressor protein menin interacts with NFkappaB proteins and inhibits NF-kappaB-mediated transactivation. Oncogene 2001, 20:4917-4925 